\title{
A Report of an ESL Classroom Observation in Two Language Schools in Auckland
}

Hong Yang

This article reports an empirical study of classroom observation of two general English lessons that examined the effects of teachers' referential questions on learners' responses in two ESL classrooms. The study found that in both classes, the teachers asked many more referential questions than display questions, contrary to earlier findings. Moreover, the teachers' referential questions elicited longer and syntactically more complex utterances from the learners. The reasons for this are discussed in the light of the objectives and pedagogic tasks of the lessons. Findings confirm the value of teachers' referential questions on learners' responses and are discussed in the context of the characteristics and functions of both referential questions and display questions.

Cet article fait rapport d'une étude empirique impliquant l'observation en classe de leçons d'anglais. L'étude portait sur les effets qu'avaient les questions référentielles des enseignants sur les réponses des apprenants dans deux cours d'ALS. L'étude a trouvé que dans les deux cours, les enseignants posaient beaucoup plus de questions référentielles que de questions illocutoires, contrairement à ce que l'on avait trouvé lors d'autres études. De plus, les questions référentielles des enseignants suscitaient, de la part des apprenants, des réponses plus longues et complexes sur le plan syntaxique. Nous expliquons ce phénomène à la lumière des objectifs et des tâches pédagogiques des leçons. Les résultats de l'étude confirment la valeur des questions référentielles des enseignants par rapport aux réponses des apprenants; nous en discutons dans le contexte des caractéristiques et des fonctions des questions référentielles et des questions illocutoires.

\section{Introduction}

This article examines the effects of teachers' referential questions on learner response in two teacher-fronted ESL classrooms in two language schools in Auckland, New Zealand. In recent years, a number of studies have been conducted into the forms and functions of teachers' questions in classroom language teaching contexts. In that research, teachers tended to ask more display questions than referential questions (Long \& Sato, 1983; Brock, 1986). This study is specifically concerned with the effects of teachers' referential questions in contrast with effects of teachers' display questions. For this 
purpose I present a small-scale study on teachers' question forms and their effects on learner response. The article begins with a brief literature review, the methods used to collect and analyze data, and then a discussion of the results of the study.

\section{Literature Review}

Researching the forms and functions of teachers' questions in secondary school classrooms in the United Kingdom, Barnes (1969, 1976, cited in Ellis, 1994) distinguished four types of questions. These were factual questions like what? and when? reasoning questions such as how? and why? open questions not requiring any reasoning, and finally social questions influencing student behavior by control or appealing.

In a cross-disciplinary study of questions and question-asking in oral discourse, Kearsley (1976) further refined Barnes' (1969) categories of teachers' questions into more detailed categories. Kearsley categorized teachers' questions into four types-echoic, epistemic, expressive, and social controlusing question functions as the dividing principle.

Later, Long and Sato (1983) conducted an exploratory investigation of the forms and functions of teachers' questions in six ESL elementary level lessons and compared the findings with previously established patterns of questioning behavior in 36 informal NS-NNS conversation outside classrooms. They compared the types of questions the teacher asked in class with the types of questions native speakers used in communication with NNS in non-classroom contexts. In the study, teachers' display and referential questions were identified and the frequency of both types of questions and the total of questions were counted respectively. They found that the teachers asked 938 questions in total. They also discovered that significantly more display questions (476) than referential questions (128) were asked by the teachers in the six ESL classroom contexts (51\% as opposed to $14 \%$ of the total of 938). In the 36 NS-NNS conversations, referential questions were predominant. Of the total of 1,322 questions asked, 999 were referential questions in contrast with two display questions ( $76 \%$ contrasting with $0.15 \%$ of the total).

In another study, Brock (1986) studied the effects of referential questions on ESL classroom discourse. The research was conducted with four experienced ESL teachers and 24 non-native speakers. Two of the teachers were trained to integrate referential questions into their classroom instruction, whereas the other two were not. Each of the teachers gave the same lesson to six of the non-native speakers, and the lessons were recorded, transcribed, and analyzed. Brock found that the two teachers who had not been trained to use referential questions asked a total of 141 epistemic questions. Of the total, 24 were referential questions and 117 were display questions. In contrast, the teachers after having been trained to use referential questions asked 194 epistemic questions altogether. Of the total, 173 were referential questions 
and 21 were display. The study showed that those learners who were asked more referential questions produced significantly longer and more syntactically complex responses. The study also revealed that a greater number of referential questions were accompanied by a greater number of confirmation checks and clarification requests by the teacher. She concluded that referential questions may increase how much learners speak in the classroom.

Thornbury (1996) performed an inservice training project to raise trainees' awareness and discovered that the effort involved in asking referential questions not only fostered greater effort and depth of processing in the learners, but also in the teachers. He urged, therefore, that teachers try to present lessons in which every question is referential.

Of the studies mentioned above, Long and Sato (1983), White and Lightbown (1984), and Brock (1986) examined the use and functions of referential questions in ESL classrooms. They identified the total number of questions and both referential and display questions. In addition, they calculated the proportion of referential and display questions to the total. However, only Brock researched the relationship between teachers' referential questions and learner response. In this study, she found that referential questions elicited longer and syntactically more complex responses from learners. Thus learner response, which is viewed as output in second-language acquisition literatures, is a worthwhile avenue of investigation. Swain (1985) noted that output plays a crucial role in prompting syntactic rather than merely semantic analysis of language. Swain argues that output, moreover, may force learners to move from the semantic, open-ended, nondeterministic, strategic processing prevalent in comprehension to the complete grammatical processing needed for producing accurate utterances. Output, therefore, would seem to have a potentially significant role in the development of syntax and morphology. In short, according to Swain, output functions in three ways; it not only functions to focus attention and to test hypotheses, but also provides opportunities for output to be consciously reflected in the process of learning.

In sum, the studies described above show that it is important to understand the relationship between referential questions and learner response. In other words, it is meaningful to investigate whether referential questions can indeed elicit longer and syntactically more complex utterances (i.e., output), particularly as they have been a significant focus of second-language classroom research.

\section{Research Questions}

1. What are the proportions of the teacher's referential questions and display questions in two 40-minute ( 2 × 40 mins.) ESL lessons? 
2. What are the effects of the teacher's referential questions on learner response compared with display questions in two ESL classroom settings?

\section{Method}

The data were collected by observing two 40-minute ESL general English lessons in two language schools in Auckland. General English lessons refer to those given to non-native speakers in order to help them develop their language skills in listening, speaking, reading, and writing to pass the IELTS test. The two language schools were selected because the learners are all non-native speakers and the teachers are native speakers, which provides the right conditions for the study. I observed and audio-recorded the two lessons in process during the semester and then transcribed them. One class was composed of 14 students of mixed nationality: one from Russia, one from Venezuela, two from Korea, and 10 from China. The second class was made up of 15 international students: 13 (dominant) from China and the other two from Vietnam and Cambodia. The English proficiency level in both classes was intermediate, a level chosen because there is likely to be more questionand-answer interaction between the teacher and the students. Both teachers were experienced native English speakers who had taught English to both native speakers and non-native speakers for over 20 years. One uses materials developed by the school, and the other uses the course book Cutting Edge for intermediate learners.

\section{Analysis of Data}

This study categorized teachers' questions according to Long and Sato's (1983) adaptation of Kearsley's (1976) taxonomy. In other words, the teacher's questions were categorized into four types in accordance with their functions: echoic, epistemic, expressive, and social control questions. In this study, the focus was only on teachers' epistemic questions.

Epistemic questions are those that seek information (Kearsley 1976).

1. In referential questions, the information sought is unknown to the questioner (Allwright \& Bailey, 1991). Examples of referential question are: (024) "How did you go in your goals? (025) "Did you achieve all of them?" "How it has transformed your life?" (all examples are from the study data).

2. In display questions, the information sought is obvious to the questioner (Chaudron, 1988). Examples of display questions are: "Then the train what?" "Which word should go in the blank?" C-units are defined as grammatically independent predications (Loban, 1963, cited in Brock, 1986).

Initially, the focus of the study was the teacher's referential questions and display questions. Therefore, both types of question were coded and their 
frequency was counted. In addition, the proportion of these two types of questions to the total of the epistemic questions was calculated.

Next the study investigated the relationship between teachers' referential questions and learner response. Learner response in the transcripts of data was, therefore, graded into four types: (a) Yes/no or monosyllabic response; (b) No response; (c) Full utterance or Extended utterance; and (d) Partial utterance (see Appendix). Examples of learners' responses are shown below.

(T: How did you go in your goals? Did you achieve all of them?)

a ... No. $\rightarrow \quad$ Yes/no or monosyllabic

T: (Can anybody remember? You should remember, Paul?)

b. S: ... $\rightarrow \quad \rightarrow \quad$ No response

(T: So what about the goals you set this week? Your goals realistic?)

c. S: Yeah, I achieved. last week I achieved my speaking goals, reading goals, and writing goals and ...

listen goals only half. $\rightarrow \quad$ Full utterances

(T: Then the train what?)

d. S: Pull in. $\quad \rightarrow \quad$ Partial utterances

The frequency of the four types of learner response to both the teacher's referential questions and display questions was also counted. In addition, the proportion of each type of learner response to the teacher's referential questions and display questions were calculated in order to measure the effects of the teacher's referential questions on learner response. The mean lengths (in words) of participants' responses to referential questions and to display questions were calculated to measure whether learners produced longer utterances in responding to the teacher's referential questions. Syntactic complexity was determined by measuring the mean number of sentencenodes (s-nodes) per communication unit (c-units) to both referential and display questions. Infinitives, gerunds, and tensed verbs can be graded as s-nodes (Brock, 1986). A c-unit "may have several sentence nodes as a consequence of having several sentences, several clauses or being a run-on or compound sentence" (Freed, 1978, p. 43, cited in Brock). Based on this, the mean number of s-nodes per c-units to both of the referential and display questions was calculated.

\section{Results}

Research question 1. In both classes, there were more referential questions than display questions. Referential questions accounted for over $80 \%$ of epistemic questions. In classroom A, the teacher asked a total of 67 epistemic questions, of which 56 were referential questions and 11 were display questions. There were a total of 46 epistemic questions in Classroom B. Of all the epistemic questions, 39 were referential and 7 were display questions. The frequency and the percentage of the teacher's questions are shown in Table 1. 
Table 1

Category of Teachers' Epistemic Questions

\begin{tabular}{lcc}
\hline Questions & Total A (\%) & Total B (\%) \\
\hline Referential questions & $56(83.58)$ & $39(84.78)$ \\
Display questions & $11(16.42$ & $7(15.22)$ \\
Total epistemic questions & 67 & 46 \\
\hline
\end{tabular}

Research question 2. Teachers' referential questions elicited longer and syntactically more complex responses from learners than display questions. Both classes were similar in that response to referential questions was characterized by full utterance $(57.37 \%$ and $55 \%$ in contrast with $11.11 \%$ and $28.57 \%$ for display questions in Classrooms A and B respectively). In Classroom $\mathrm{A}$, the mean length of learner turns in responding to referential questions was approximately 7 words, whereas the mean length of the participants' responses to display questions was 2 words. In Classroom B, the mean length of learner responses to referential questions was 5.14 words, whereas the mean length was 1.6 words for display questions. The frequency and proportion of the learner response to the teacher's referential question are shown in Table 2.

The frequency and proportion of learner response to the teacher's display questions are shown in Table 3.

In addition, in classroom A, no response made up most of the participants' responses to the teacher's display questions, approximately $55 \%$ in contrast with $9.8 \%$ of no response to the referential questions.

In terms of complexity of response, both classes were similar in that response to display questions was characterized by lower complexity. The mean number of s-nodes per c-unit in responding to referential questions was 1.21 and 0.58 for Classrooms A and B respectively. The mean number of s-nodes per c-unit for display questions was 0.40 and 0.25 for Classrooms A and $\mathrm{B}$ respectively.

In summary, over $80 \%$ of the questions were referential. Over $50 \%$ of the referential questions elicited longer and syntactically more complex re-

Table 2

Learner Response to Teacher's Referential Questions

\begin{tabular}{lcc}
\hline Learner responses & Total A (\%) & Total B (\%) \\
\hline Yes/no or monosyllabic & $9(17.7)$ & $14(23.33)$ \\
No response & $5(9.8)$ & $10(16.67)$ \\
Full utterance & $35(57.37)$ & $33(55)$ \\
Partial utterance & $2(3.9)$ & $3(5)$ \\
\hline
\end{tabular}


Table 3

Learner Response to Teacher's Display Questions

\begin{tabular}{lcc}
\hline Learner responses & Total A (\%) & Total B (\%) \\
\hline Yes/no or monosyllabic & $2(18)$ & $1(14.29)$ \\
No response & $6(55)$ & $3(42.86)$ \\
Full utterance & $1(11.11)$ & $2(28.57)$ \\
Partial utterance & $2(18)$ & $1(14.29)$ \\
\hline
\end{tabular}

sponses, whereas over $60 \%$ of the display questions led to monosyllabic or no response.

\section{Discussion}

Teachers' questions function in numerous ways in the classroom. They can be used to elicit information, to check comprehension, and also to control learner behavior (Nunan \& Lamb, 1996). They serve the purposes of socializing, scene-setting, checking comprehension, evaluating learning, and seeking information (Sinclair \& Coulthard, 1975). It can be seen from the data that the teacher's referential questions can motivate more student involvement as in the following example.

(T: Good player?)

S1: No, but I know how to play.

S2: No. I never play.

S3: It's interesting.

S4: Expensive in my country (Venezuela).

The results of data analysis in this study differed from those of Long and Sato's (1983) study in two respects. First, in this study, the teacher asked many more referential questions than display questions. In contrast, only 11 display questions were asked by the teacher. Conversely, referential questions, which usually predominate in NS-NNS conversations outside classroom settings, constituted four times as many instances as display questions (59\% compared with $11 \%$, Long \& Sato, 1983). This major difference from the Long and Sato study stemmed from factors such as class size, the objectives of the lesson, the pedagogic goals, and the particular pedagogic tasks in the lesson (Nunan \& Lamb, 1996). These factors are important because the teachers' questions are restrained by and dependent on these factors. Both classes were small with only 14 and 15 learners respectively. It was, therefore, possible for the teacher to use referential questions to promote learners' involvement in language communication with the teacher and among themselves and to get information from them. Moreover, the objectives in both lessons in this study were to develop the students' speaking abilities, a 
difference from Long and Sato's study. Also, The pedagogic goal was to check whether the students had reached the goals that they had set for themselves for the past week in classroom A and how the students performed discussion-based questions in Classroom B, in contrast to Long and Sato's study.

The pedagogic tasks in both lessons observed in this study were primarily discussion-based: what one had done for the past week, if he or she had reached his or her own goal in Classroom A and questions for discussion about transport and students' lives such as Has anything changed since you came to New Zealand? The tasks started with explanation and instruction as to what students were required to do (a fill-in exercise and discussion questions respectively), reviewing what they had learned during the last period. The teacher asked some display questions during the process to ensure background knowledge and understanding. The students were then required to discuss whether they had achieved the goals they had set for themselves for the past week. For this, referential questions were used to elicit information from the learners; their responses were open and unknown to the teacher. These referential questions were used in order to motivate the learners to draw on their background knowledge to produce their own answers. For example, in Classroom A, although the question was the same, the students' responses varied because each had different ideas about his or her goals, as is shown below.

(T: What else are you going to?)

S1: Introduce something interesting.

(T: Paul and Bill? What are you going to do?)

S2: To the students' lounge.

(T: And you girls? What are you going to do?)

S3: We are going to, going to the movie, and after the movie we'll coffee ... and talk about the movie.

(T: Do you have a clue?)

S4: She needs to enjoy to learn.

In sum, choice of question type may be dependent on the size of the class, the objectives of the lesson, the pedagogic goals, and the tasks in the lesson. It is up to the teacher to decide whether and when to ask referential questions (Nunan \& Lamb, 1996).

Second, the difference in the language produced by learners in response to the two types of questions was pronounced. In this study, the students in both classes produced utterances that were on average more than three times longer in responding to referential questions than to display questions. Moreover, the students provided responses to referential questions that were on average twice as syntactically complex as responses to display questions in Classroom A. Similarly, syntactically more complex responses to referen- 
tial questions doubled those to display questions in Classroom B. In these data, the learner responses to display questions were primarily monosyllabic or partial utterances, as can be seen in here.

(T: Then the train what?)

S: Pull in.

(T: Which word should go in the blank?)

S: Awkward.

(T: What is the other word that could go in the blank?)

S: Hazardous.

In contrast, responses to referential questions were principally full utterances:

(T: So what about the goals you set this week? What do you think you can do?)

S: Yeah, I achieved. Last week I achieved my speaking goals, reading goals, and writing goals and ... listen goals only half.

(T: Do you think you might have your goals maybe too big? Maybe, maybe ...)

S: I know. Therefore, I only achieved only speaking goals, but listening and writing only half ...

S: If I want to study English very good, I think I have to maybe enjoy it.

There are a number of reasons for this difference in response to referential questions and display questions. Referential questions are open questions in which the questioner seeks information (Chaudron, 1988). They extend beyond the reach of other types of questions. Because referential questions are open questions for which the teacher does not know the answer, the effort involved in answering them stimulates greater effort and depth of processing on the part of the leaner (Thornbury, 1996). Referential questions would be likely, therefore, to promote greater learner productivity (Chaudron).

In addition, referential questions call for assessment or judgment (Brock, 1986). Thus referential questions can stimulate more productive and varied use of English (Cullen, 1998). Because referential questions are open questions, they are more likely to encourage learners to participate actively and to bring their own thoughts and recollections into the conversation (Barnes, 1969, 1976, cited in Ellis 1994). This is true of my data.

(T: What about you, Bill? How did you go?)

S: Understanding teacher. Keep the same.

(T: Not useful? How would you try this week?)

S: Maybe this week I will change my goal.

(T: You'll change your goal? What's your goals this week?)

$\mathrm{S}$ : More conversation ... and practice my pronunciation. 
Brock (1986) suggests that the use of referential questions, moreover, can create a flow of information from learners to teachers, thus generating discourse resembling the outside classroom conversations that learners experience. An example from this study supports Brock's suggestions.

(T: How have you done? What strategies?)

S: I don't know "strategies." I look more and more time.

(T: What are you going to do to change that this week?)

S: We try to finish last week's work and do some new goals. I think a little bit tired and we'll write more and exchange ideas with each other.

Maybe I feel I'm very lazy. I don't want ...

Similarly, learner response (i.e., output) serves as feedback to help teachers maintain interaction with students and also functions to help learners with self-correction (Gass, 1997). In particular, longer and syntactically more complex learner output elicited by referential questions can enhance the development of syntax and morphology in language learners (Swain, 1995).

By contrast, display questions are those that oblige learners to display knowledge. They are used in order to elicit learners' knowledge of the answers to these types of questions (Long \& Sato, 1983). They ask for recognition or recall of factual information. Chaudron (1988) notes that display questions tend to be closed questions. It is possible, therefore, that learners provide the information for such types of questions for didactic purposes only. It is implied that the display of a correct answer is the primary objective of a teacher's display question (Korst, 1997, cited in Chaudron, 1988). Thus display questions are likely to elicit short answers that motivate less communicative involvement.

\section{Conclusion}

Through observation and transcription of teacher-student discourse in two classrooms, this study has contrasted the effects of teachers' referential questions and display questions on learner response. The study indicates that there were many more referential questions than display questions in the two ESL classrooms. It also reveals that teacher's referential questions elicited longer and more complex syntactic responses from the learners. These findings suggest that factors such as class size, the pedagogic goals, and tasks in a lesson strongly affect whether and when referential questions or display questions should be used. Finally, given the importance and the need for teachers' referential questions in encouraging learner output, it would appear necessary for teachers to provide topic-based tasks in class. A further implication of these findings is that it would be helpful for teachers to use as many referential questions as possible in order to enhance learners' engagement in communicative language use (Thornbury, 1996). 


\section{Acknowledgment}

I thank my teacher Dr. Jenefer Philp at the University of Auckland for her critical reading of earlier drafts of this article. Her help in developing this article was invaluable.

\section{The Author}

Hong Yang is an associate professor in the Foreign Language Department in Chansha University. In 2004 he graduated from the University of Auckland with a Master of Professional Studies (Language Teaching).

\section{References}

Allwright, D., \& Bailey, K.M. (1991). Focus on the language classroom: An introduction to classroom research for language teachers. Cambridge, UK: Cambridge University Press.

Barnes, D. (1969). Language in the secondary classroom. In D. Barnes, J. Britton, \& M. Torbe (Eds.), Language, the learner and the school. Harmondsworth, UK: Penguin.

Barnes, D. (1976). From communication to curriculum. Harmondsworth, UK: Penguin.

Brock, C. (1986). The effects of referential questions on ESL classroom discourse. TESOL Quarterly, 20, 47-59.

Chaudron, C. (1988). Second language classrooms: Research on teaching and learning. Cambridge, UK: Cambridge University Press.

Cullen, R. (1998). Teacher talk and the classroom context. ELT Journal, 52(3), 179-187.

Ellis, R. (1994). The study of second language acquisition. Oxford, UK: Oxford University Press.

Freed, B.F. (1978). Foreigner talk: A study of speech adjustments made by native speakers of English in conversation with non-native speakers. Unpublished doctoral dissertation, University of Pennsylvania, Philadelphia.

Gass, S. (1997). Input, interaction and the second language learner. Mahwah, NJ: Erlbaum.

Kearsley, G.P. (1976). Questions and question asking in verbal discourse: A cross-disciplinary review. Journal of Psycholinguistic Research, 5, 355-375.

Korst, T.J (1997). Answer, please answer! A perspective on Japanese university students' silent responses to questions. JALT Journal, 19, 279-291.

Loban, W. (1963). The language of elementary school children (Research Report No. 1). Champlain, IL: National Council of Teachers of English.

Long, M.H., \& Sato, C.J. (1983). Classroom foreign talk discourse: Forms and functions of teachers' questions in classroom oriented research in second language acquisition. In $\mathrm{H}$. Seliger \& M. Long (Eds.), Classroom oriented research in second language acquisition (pp. 268-286). Rowley, MA: Newbury House.

Nunan, D., \& Lamb, C. (1996). The self-directed teacher: Managing the learning process. Cambridge, UK: Cambridge University Press.

Sinclair, J.M., \& Coulthard, R.M. (1975). Towards an analysis of discourse: The English used by teachers and pupils. London, UK: Oxford University Press.

Swain, M. (1985). Communicative competence: Some roles of comprehensible input and comprehensible output in its development. In S. Gass \& C. Madden (Eds.), Input in second language acquisition (pp. 235-253). Rowley, MA: Newbury House.

Swain, M. (1995). Three functions of output in second language learner. In G. Cook \& B. Seidlehofer (Eds.), Principle and practice in applied linguistics (pp. 125-144). Oxford, UK: Oxford University Press.

Thornbury, S. (1996). Teachers research teacher talk. ELT Journal, 50, 279-289.

White, L., \& Lightbown, P. (1984). Asking and answering in ESL classes. Canadian Modern Language Regview, 40, 288-344. 